\title{
PREVALENCE OF THYROID DYSFUNCTION IN CHRONIC KIDNEY DISEASE
}

\author{
G. Prabhu1, Nandhini Priyanka B2, Rajaprabhu J3, Linto Mathew Thomas 4
}

${ }^{1}$ Reader, Department of Medicine, Rajah Muthiah Medical College.

2Postgraduate, Department of Medicine, Rajah Muthiah Medical College.

3Pharm. D (Internship), Annamalai University.

4Pharm. D (Internship), Annamalai University.

\section{ABSTRACT}

\section{AIM}

The present study was aimed to study the Prevalence of thyroid dysfunction in chronic kidney disease at RMMCH.

\section{METHODS AND MATERIALS}

The data was collected from the patients reported to dialysis unit, OPD and wards in Rajah Muthiah Medical College Hospital, Annamalai University. During a period of 2 months, 60 patients who had undergone treatment for chronic kidney disease were followed up (Male-24, Female-36). Patients with chronic kidney disease confirmed by Ultrasonography of kidney and Creatinine clearance, patients on haemodialysis/renal replacement therapy or Conservative treatment were included in this study. Patients on Thyroid replacement/Anti-Thyroid drugs, Age $<30$ years, Patients on steroid/hormone therapy and Malignancy were excluded in this study.

\section{RESULTS}

60 patients (24 males and 36 females) were included in the study. From the study, incidence rate was identified more in the age group of 51-60 years of age. As per the study conducted, about 12 patients were non-diabetic and 9 were not hypertensives; 36 patients undergone the treatment of haemodialysis and 24 patients were on conservative treatment. In our study, there were 13 patients (21.66\%) with hypothyroidism. Of which, clinical features and investigations revealed 6 patients with clinical hypothyroidism and 7 patients with subclinical hypothyroidism with stages 1-5 CKD. No patient had clinical evidence of hyperthyroidism.

\section{CONCLUSION}

In summary, the present study finds hypothyroidism to be very common in CKD patients and reveals the significant association between CKD progression and thyroid dysfunction.

\section{KEYWORDS}

Thyroid Dysfunction, Chronic Kidney Disease, Hypothyroidism.

HOW TO CITE THIS ARTICLE: Prabhu G, Priyanka NB, Rajaprabhu J, et al. Prevalence of thyroid dysfunction in chronic kidney disease. J. Evolution Med. Dent. Sci. 2016;5(73):5378-5380, DOI: 10.14260/jemds/2016/1220

\section{INTRODUCTION}

Abnormalities in thyroid function tests are frequently encountered in uraemia. However, the overlap in symptomatology between the uremic syndrome and hypothyroidism requires a cautious interpretation of these tests. Nevertheless, it is ordinarily possible in the individual uraemic patient to assess thyroid status accurately by physical diagnosis and thyroid function testing. Epidemiologic data suggests that predialysis patients with chronic kidney disease have an increased rate of hypothyroidism.[1-4] Patients with chronic renal failure often have signs and symptoms suggestive of thyroid dysfunction.

Financial or Other, Competing Interest: None.

Submission 06-08-2016, Peer Review 29-08-2016,

Acceptance 05-09-2016, Published 12-09-2016.

Corresponding Author:

Dr. G. Prabhu,

Reader,

Department of Medicine,

Rajah Muthiah Medical College,

Annamalai University.

E-mail: kggprabhu@gmail.com

DOI: $10.14260 /$ jemds $/ 2016 / 1220$
These findings include dry skin, sallow complexion, low temperature, cold intolerance, decreased basal metabolic rate, lethargy, fatigue, oedema and hyporeflexia. Various studies of thyroid functions in uremic patients have been carried out, which have shown conflicting results. Hyperthyroidism, hypothyroidism and euthyroid state have all been reported. ${ }^{[5-7]}$ Chronic kidney disease is associated with multiple disturbances in thyroid metabolism that are manifested in low serum free and total T3 levels and normal in total T3 and free T4 concentrations. The serum TSH concentration is normal and most patients are euthyroid.[8] Free fatty acids and heparin also interfere with $\mathrm{T} 4$ binding to TBG. Thus, the routine use of heparin to prevent clotting in the dialysis tubing may explain the transient elevation in serum T4 levels that commonly occurs during haemodialysis. ${ }^{[9]}$

\section{Thyroid Hormone Metabolism and the Kidney}

Due to reduced deiodinase activity, tissue and circulating levels of the active form of the thyroid hormone (T3) is low in kidney failure.[10] Because of reduced renal excretion, inorganic iodide generated by residual deiodinase activity accumulates in stage 4 and 5 CKD, which in turn dampens thyroid hormone synthesis. On the other hand, accumulation of toxic uraemic solutes alters the central (Hypothalamic) 
control of the pituitary gland, and the TSH response to thyrotropin releasing hormone is subnormal in patients with kidney failure.[11] In contrast, the thyroid-pituitary feedback loop seems to remain intact, because steady-state plasma TSH remains substantially normal and TSH undergoes the expected rise after thyroidectomy in these patients.[7] Central effects apart, toxic uraemic solutes such as urea, creatinine, indoles and phenols inhibit protein binding of T4.[12] Furthermore, studies in the last decade showed that systemic inflammation[13,14] and metabolic acidosis[15] may alter thyroid function in CKD patients.

\section{METHODS AND MATERIALS}

A total number of 60 randomly selected patients with chronic kidney disease attending dialysis unit, OPD and admitted in Rajah Muthiah Medical College Hospital were studied between April 2016 to June 2016. Study population consisting of 24 male and 36 female patients who were diagnosed cases of chronic kidney disease. Age range was 3170 years. Most patients in this study were on conservative treatment and a few were on renal replacement therapy (Peritoneal or haemodialysis).

\section{Inclusion Criteria}

1. Patients with chronic kidney disease confirmed by Ultrasonography of kidney and Creatinine clearance.

2. Patients on haemodialysis, Renal replacement therapy, Conservative (Medical treatment).

\section{Exclusion Criteria}

1. Patients on thyroid replacement/anti-thyroid drugs.

2. Age $<30$ years.

3. Patients on steroid/hormone therapy.

4. Malignancy.

\section{Data Collection}

Data was collected from the patients reported to dialysis unit, OPD and wards in RMMCH, Annamalai University. Initially, we recorded demographic information (Name, sex, age, etc.), the presence of kidney disease and its complications, past history (Such as acute and chronic infections or chronic diseases) of all enrolled subjects. Blood samples were collected from the peripheral vein and analysed for indicators of renal function (Creatinine, Cr; Blood Urea Nitrogen, BUN; Uric Acid, UA), and for thyroid function (Serum free T3 (FT3), free T4 (FT4), and Thyroid Stimulating Hormone (TSH). Routine urine samples were taken and urinary protein assayed; kidney ultrasound was also performed to assist in evaluating the severity of illness. Thyroid function tests were performed using an electrochemiluminescence assay. The normal reference ranges for FT3, FT4 and TSH in our hospital's clinical laboratory were $1.4-4.4 \mathrm{pg} / \mathrm{mL}, 0.7-2.0$ $\mathrm{ng} / \mathrm{dL}$, and $0.30-5.5 \mu \mathrm{IU} / \mathrm{mL}$ respectively. The data was statistically analysed.

\section{RESULTS}

\begin{tabular}{|c|c|c|c|}
\hline Age & Male & Female & Total \\
\hline 31-40 years & 4 & 6 & 10 \\
\hline 41-50 years & 7 & 11 & 18 \\
\hline 51-60 years & 6 & 15 & 21 \\
\hline 61-70 years & 7 & 4 & 11 \\
\hline Total & 24 & 36 & 60 \\
\hline \multicolumn{3}{|c|}{ Table 1: Age \& Sex Wise Distribution } \\
\hline
\end{tabular}

\begin{tabular}{|c|c|c|c|c|c|}
\hline \multirow[b]{2}{*}{ Age } & \multicolumn{4}{|c|}{ Duration of Diabetes Mellitus } & \multirow[b]{2}{*}{$\begin{array}{c}\text { No. of } \\
\text { Patients }\end{array}$} \\
\hline & $\begin{array}{c}1-2 \\
\text { years }\end{array}$ & $\begin{array}{c}2-5 \\
\text { years }\end{array}$ & $\begin{array}{c}5-10 \\
\text { years }\end{array}$ & $\begin{array}{c}>10 \\
\text { years }\end{array}$ & \\
\hline $31-40$ & 2 & 2 & 2 & - & 6 \\
\hline $41-50$ & 1 & 2 & 4 & 3 & 10 \\
\hline $51-60$ & - & 7 & 5 & 9 & 21 \\
\hline $61-70$ & - & 4 & 3 & 4 & 11 \\
\hline Total & 3 & 15 & 14 & 16 & 48 \\
\hline
\end{tabular}

\begin{tabular}{|c|c|c|c|c|c|}
\hline \multirow[b]{2}{*}{ Age } & \multicolumn{4}{|c|}{ Duration of Hypertension } & \multirow[b]{2}{*}{$\begin{array}{c}\text { No. of } \\
\text { Patients }\end{array}$} \\
\hline & $\begin{array}{c}1-2 \\
\text { years }\end{array}$ & $\begin{array}{c}2-5 \\
\text { years }\end{array}$ & $\begin{array}{c}5-10 \\
\text { years }\end{array}$ & $\begin{array}{c}>10 \\
\text { years }\end{array}$ & \\
\hline $31-40$ & 2 & 2 & 6 & - & 10 \\
\hline $41-50$ & 1 & 2 & 9 & 6 & 18 \\
\hline $51-60$ & - & 7 & 5 & 4 & 16 \\
\hline $61-70$ & - & - & 4 & 3 & 07 \\
\hline Total & 3 & 11 & 24 & 13 & 51 \\
\hline \multicolumn{6}{|c|}{ Table 3: Age vs. Duration of Hypertension } \\
\hline
\end{tabular}

\begin{tabular}{|c|c|c|c|}
\hline Variables & $\mathbf{n}$ & $\begin{array}{c}\text { Reference } \\
\text { Range }\end{array}$ & $\pm \mathbf{s}$ \\
\hline FT3 $(\mathrm{pg} / \mathrm{mL})$ & 60 & $1.4-4.4$ & $1.834 \pm 0.018$ \\
\hline FT4 $(\mathrm{ng} / \mathrm{dL})$ & 60 & $0.7-2.0$ & $1.5 \pm 0.51$ \\
\hline TSH $(\mu \mathrm{IU} / \mathrm{mL})$ & 60 & $0.30-5.5$ & $3.62 \pm 2.48$ \\
\hline \multicolumn{2}{|c|}{ Table 4: Thyroid Function in (n=60) Enrolled Subjects } \\
\hline
\end{tabular}

\begin{tabular}{|c|c|c|}
\hline CKD Stage & No. of patients & Percentage \\
\hline Stage 1 & 10 & $16.66 \%$ \\
\hline Stage 2 & 7 & $11.66 \%$ \\
\hline Stage 3 & 2 & $3.33 \%$ \\
\hline Stage 4 & 5 & $8.33 \%$ \\
\hline Stage 5 & 36 & $60 \%$ \\
\hline Total & 60 & $100 \%$ \\
\hline \multicolumn{2}{|c|}{ Table 5: CKD Stage vs. No. of Patients } \\
\hline
\end{tabular}

\begin{tabular}{|c|c|c|}
\hline Treatment & No. of Patients & Percentage \\
\hline Haemodialysis (Stage 5) & 36 & $60 \%$ \\
\hline $\begin{array}{c}\text { Conservative treatment } \\
\text { (Stage 1-4) }\end{array}$ & 24 & $40 \%$ \\
\hline Total & 60 & $100 \%$ \\
\hline \multicolumn{2}{|c|}{ Table 6: Treatment of CKD } \\
\hline
\end{tabular}




\begin{tabular}{|c|c|c|c|c|c|c|c|}
\hline \multicolumn{2}{|c|}{ Variables } & Stage 1 & Stage 2 & Stage 3 & Stage 4 & Stage 5 & Total $(n=60)$ \\
\hline \multirow{3}{*}{ FT3 } & Low & $1(10 \%)$ & $2(28.57 \%)$ & - & $1(20 \%)$ & $9(25 \%)$ & $13(21.66 \%)$ \\
\hline & Normal & $8(80 \%)$ & $5(71.42 \%)$ & $1(50 \%)$ & $4(80 \%)$ & $27(75 \%)$ & $45(75 \%)$ \\
\hline & High & $1(10 \%)$ & - & $1(50 \%)$ & - & - & $2(3.33 \%)$ \\
\hline \multirow{3}{*}{ FT4 } & Low & $1(10 \%)$ & $2(28.57 \%)$ & $1(50 \%)$ & $2(40 \%)$ & $9(25 \%)$ & $15(25 \%)$ \\
\hline & Normal & $8(80 \%)$ & $5(71.42 \%)$ & $1(50 \%)$ & $2(40 \%)$ & $27(75 \%)$ & $43(71.66 \%)$ \\
\hline & High & $1(10 \%)$ & - & - & $1(20 \%)$ & - & $2(3.33 \%)$ \\
\hline \multirow{3}{*}{ TSH } & Low & - & $1(14.28 \%)$ & $150 \%)$ & - & - & $2(3.33 \%)$ \\
\hline & Normal & $9(90 \%)$ & $4(57.14 \%)$ & - & $4(80 \%)$ & $28(77.77 \%)$ & $45(75 \%)$ \\
\hline & High & $1(10 \%)$ & $2(28.57 \%)$ & $1(50 \%)$ & $1(20 \%)$ & $8(22.22 \%)$ & $13(21.66 \%)$ \\
\hline
\end{tabular}

\section{DISCUSSION}

A total number of 60 patients were enrolled in this study. The mean age was $50.65 \pm 9.404$ years. There were 36 female patients and 24 male patients as compared to other study, which enrolled 14,623 patients, the mean age was $48.7 \pm 18.9$ years. There were 7671 women and 6952 men (Lo et al).[1] The maximum number of patients were in the age group of 51-60 years (21 patients), while the female patients were more in this group than in male. Minimum number of patients were in the age group of 31-40 years (10 patients). As per the study conducted, about 12 patients were non-diabetic and 9 were not hypertensive. But diabetes mellitus and hypertensive nephropathy were contributing too significantly for the cause of CKD. In our study, prevalence of diabetes mellitus and hypertension was 80 and $85 \%$ in stage 1-5 CKD patients. In a similar study conducted by (Khatiwada et al), prevalence of diabetes mellitus and hypertension was 45.8 and $63.8 \%$ in stage $3 ; 40.3$ and $72.4 \%$ in stage $4 ; 60$ and $80 \%$ in stage 5 CKD patients respectively.[16] In our study, mean variables in thyroid function tests were FT3 $(1.834 \pm 0.018)$, FT4 (1.5 \pm 0.51$)$ and TSH $(3.62 \pm 2.48)$. In the study conducted, 36 patients underwent the treatment of haemodialysis and 24 patients were on conservative treatment. In our study, there were 13 patients $(21.66 \%)$ with hypothyroidism of which clinical features and investigation revealed 6 patients with clinical hypothyroidism and 7 patients with subclinical hypothyroidism of stages 1-5 CKD. A similar study showed 8 patients (16\%) with hypothyroidism were from stages 4 and 5 CKD (Ali A. Allawi).[17] In our study we noted a significant decrease in mean FT3, FT4 and increase in TSH mean. Also in our study we noted 13 patients, in which 5 patients were managed by conservative treatment and 8 with haemodialysis. No patient demonstrated hyperthyroidism factors and investigations also did not reveal clear evidence of hyperthyroidism in this study.

\section{CONCLUSION}

The present study was aimed to study the prevalence of thyroid dysfunction in chronic kidney disease at RMMCH. In summary, the present study finds hypothyroidism to be very common in CKD patients and reveals the significant association between CKD progression and thyroid dysfunction.

\section{REFERENCES}

1. Lo JC, Chertow GM, Go AS, et al. Increased prevalence of subclinical and clinical hypothyroidism in persons with chronic kidney disease. Kidney Int 2005;67(3):1047-52.
2. Chonchol M, Lippi G, Salvagno G, et al. Prevalence of subclinical hypothyroidism in patients with chronic kidney disease. Clin J Am Soc Nephrol 2008;3(5):1296300.

3. Ingbar HS, Woeber AK. The thyroid gland. In: Williams RH, (ed). The textbook of endocrinology. $5^{\text {th }}$ edn. Philadelphia: WB Saunders Company 1977:174.

4. Schmidt P, Stobaeus N, Prame G, et al. Exophthalmos inchronic renal insufficiency. Scand J Urol Nephrol 1971;5(2):146-53.

5. Kalz AI, Emmanouel DS, Lindheimer MD. Thyroid hormone and the kidney. Nephron 1975;15(3-5):223-49.

6. Yashpal. Thyroid function in uraemia. Ind J Nephrol 1991;1(2).

7. Spector DA, Davis PJ, Helderman JH, et al. Thyroid function and metabolic state in chronic renal failure. Ann Int Med 1976;85(6):724-30.

8. Medri G, Carella C, Padmanaban V, et al. Pituitary glycoprotein hormones in chronic renal failure: evidence for an uncontrolled alpha-subunit release. J Endocrinol Invest 1993;16(3):169-74.

9. Cheng SY. Thyroid hormone receptor mutations and disease: beyond thyroid hormone resistance. Trends Endocrinol Metab 2005;16(4):176-82.

10. Kaptein EM. Thyroid hormone metabolism and thyroid diseases in chronic renal failure. Endocr Rev 1996;17(1):45-63.

11. Czernichow P, Dauzet MC, Broyer M, et al. Abnormal TSH, PRL and GH response to TSH releasing factor in chronic renal failure. J Clin Endocrinol Metab 1976;43(3):630-7.

12. Spaulding SW, Gregerman RI. Free thyroxine in serum by equilibrium dialysis: effects of dilution, specific ions and inhibitors of binding. J Clin Endocrinol Metab 1972;34(6):974-82.

13. Zoccali C, Tripepi G, Cutrupi S, et al. Low triiodothyronine: a new facet of inflammation in endstage renal disease. J Am Soc Nephrol 2005;16(9):278995.

14. Carrero JJ, Qureshi AR, Axelsson J, et al. Clinical and biochemical implications of low thyroid hormone levels (total and free forms) in euthyroidpatients with chronic kidney disease. J Intern Med 2007;262(6):690-701.

15. Wiederkehr MR, Kalogiros J, Krapf R. Correction of metabolic acidosis improves thyroid and growth hormone axes in haemodialysis patients. Nephrol Dial Transplant 2004;19(5):1190-7.

16. Khatiwada S, Rajendra KC, Gautam S, et al. Thyroid dysfunction and dyslipidemia in chronic kidney disease patients. BMC Endocrine Disorders 2015;15:65.

17. Allawi AA. Prevalence of hypothyroidism in chronic kidney disease among sample of iraqi patients. J Fac Med Baghdad 2013;55(2):97-101. 